\title{
Chemistry and Biodiversity of Rhizophora-Derived Endophytic Fungi
}

\author{
Jing Zhou and Jing Xu \\ Additional information is available at the end of the chapter \\ http://dx.doi.org/10.5772/intechopen.76573
}

\begin{abstract}
Rhizophora are salt-tolerant mangrove flora located in tropical and subtropical intertidal coastal regions. This review summarizes frequently occurring fungal endophytes in Rhizophora. In total, 41 families and 64 genera belonging to 23 taxonomic orders of Ascomycota have been reported. Among those discussed here, Pestalotiopsis, Penicillium, and Mucor are the most abundant fungal genera, and they are widely studied. In previous studies, 195 metabolites were encountered in Rhizophora-derived endophytic fungi, and their structures are reported within a biogenetic context. Bioassays showed antitumor, antimicrobial, as well as anti-H1N1 activities to be the most notable bioactivities of the secondary metabolites discussed.
\end{abstract}

Keywords: Rhizophora-derived endophytic fungi, biodiversity, secondary metabolites, biological activities

\section{Introduction}

Endophytic fungi, a polyphyletic group of highly diverse, primarily ascomycetous fungi that spend all or at least for a part of their life cycle inter- or intracellularly colonizing healthy tissues of plants without causing visible disease symptoms [1]. They are found in almost all vascular plants and grass plants [2]. It is worth noting that of the nearly 300,000 plant species that exist on Earth, any given plant is colonized by several to few hundreds of endophytic fungal species. Only a few of these plants have ever been completely studied relative to their endophytic biology [3]. Until recently, extensive work has been conducted on traditionally investigated terrestrial endophytic fungi with biological significance, and these studies mostly concentrated on the tropical and rainforest regions of the world. However, systematic 
and comparative approaches to identifying endophytic fungi and their specific location in the plants they colonize, especially in ecological niches such as mangrove endosymbionts growing in high salinity, high temperature, extreme tides, oxygen pressure, high humidity, and light and air limitations, have received considerable attention in recent decades [4, 5]. Hence, it is now generally accepted that the highly complex mangrove ecosystems could act as an effective selector for metabolic pathway evolution via the generation of structurally unprecedented and biologically interesting metabolites of pharmaceutical importance. Such metabolites are believed to be involved in ecological adaptability, defense, communication, and predation [6]. In this review, we summarize the biodiversity of Rhizophora endophytic fungi. Additionally, the metabolites encountered in Rhizophora-derived endophytic fungi and their structures are reported within a biogenetic context. Special emphasis is placed on the prospect of discovering unique functional metabolites.

\section{Endophytic fungi from Rhizophora}

Mangroves are composed of a large group of salt-tolerant plant communities growing in tropical and subtropical intertidal estuarine zones, which are distributed approximately in the area between $30^{\circ} \mathrm{N}$ and $30^{\circ} \mathrm{S}$ latitude [7]. Asia and Australia have the greatest diversity and distribution of mangrove species. Among the 18 million hectares of mangrove forests, more than $40 \%$ are found along the Asian coasts, including the South China Sea Coast [10]. The most established mangroves can be found in Bangladesh, Brazil, Indonesia, India, and Thailand [8,9]. According to the statistical data of the International Society of Mangrove Ecosystem, there are 84 mangrove species globally, belonging to 16 families and 24 genera. Among them, 70 species are true mangroves, pertaining to 16 genera and 11 families. Another 14 species are considered semimangroves, belonging to 8 genera and 5 families [10]. China has 26 species, and 24 of them are distributed in Hainan [11, 12].

Rhizophora is one of the most conspicuous genera of the most widespread mangrove family, the Rhizophoraceae. The genus is relatively old among cosmopolitan mangrove genera, and it has notable discontinued species distributions [13]. In total, eight species comprise the Rhizophora, including $R$. stylosa, R. apiculata, R. mucronata, R. mangle, R. harrisonii, $R$. racemosa, $R$. annamalayana, and $R$. samoensis (Table 1). R. stylosa, R. mucronata, and $R$. apiculata are mainly distributed in islands and coastal areas bordering the Pacific Ocean and the Indian Ocean, while $R$. mangle, $R$. annamalayana, $R$. samoensis, $R$. harrisonii, and R. racemosa are mainly distributed from the eastern Pacific through the American islands to the Atlantic Ocean (Figure 1).

Fungi colonized in mangrove forests, which comprise the second largest ecological group of the marine fungi, have specially adapted their own morphological structures and physiological mechanisms to promote the survival of host plants in harsh environmental conditions through long-term endophyte-host interactions [52]. Most mangrove endophytic fungi are facultative halophiles and euryhaline in nature. Since they do not require added salt for growth, they are able to grow at high salt concentrations and show a balanced symbiotic continuum of mutualism with host mangroves [5]. For instance, the halotolerant Rhizophora stylosa 


\begin{tabular}{|c|c|c|}
\hline Plants species & Distribution & Ref. \\
\hline R. stylosa & $\begin{array}{l}\text { China (Hainan, Guangdong, Guangxi); } \\
\text { Philippines; New Caledonia; Fiji } \\
\text { (Viti Levu); Australia; Japan (Ryukyu } \\
\text { Archipelago) }\end{array}$ & $\begin{array}{l}\text { Hainan plant flora [12]; Xing [14]; Villamayor [15]; } \\
\text { Dangan [16]; Morton [17]; Arfi [18]; Chen [11]; Tyagi } \\
\text { [19]; Kohlmeyer [20] }\end{array}$ \\
\hline R. apiculata & $\begin{array}{l}\text { China (Hainan, Guangdong, Guangxi); } \\
\text { India; Indonesia; Philippines; Vietnam; } \\
\text { Thailand; Singapore; Malaysia }\end{array}$ & $\begin{array}{l}\text { Hainan plant flora [12]; Xing [14]; Selvaraj [21]; } \\
\text { Villamayor [15]; Dangan [16]; Rossiana [22]; Clough } \\
\text { [23]; Piapukiew [24]; Klaiklay, [25]; Rukachaisirikul [26]; } \\
\text { Tan [27] }\end{array}$ \\
\hline R. mucronata & $\begin{array}{l}\text { China (Taiwan); Vietnam; South Africa; } \\
\text { Philippines; Indonesia; India; Thailand; } \\
\text { Japan; Singapore; Pakistan }\end{array}$ & $\begin{array}{l}\text { Hainan plant flora [12]; Trinh [28]; Osorio [29]; } \\
\text { Villamayor [15]; Dangan [16]; Tarman [30]; } \\
\text { Suryanarayanan [31]; Rani [32]; Kandasamy [33]; } \\
\text { Rukachaisirikul [26]; Tan [27]; Tariq [34] }\end{array}$ \\
\hline R. mangle & $\begin{array}{l}\text { Brazil; Venezuela; Dominican Republic; } \\
\text { Gua de Ropp; Mexico; America } \\
\text { (Florida, Hawaii); Senegal; Gabon; } \\
\text { French Guiana; Australia }\end{array}$ & $\begin{array}{l}\text { Boehm [35]; Ferreira [36]; Barreto [37]; Ball [38]; Afzal } \\
\text { [39]; Wanderley [40]; Dourado [41]; Godoy [42]; } \\
\text { Kohlmeyer [20] }\end{array}$ \\
\hline R. harrisonii & $\begin{array}{l}\text { Nigeria (Port Harcourt); Ecuador; } \\
\text { America; West Africa; Equatorial } \\
\text { Guinea; Senegal; Gabon }\end{array}$ & $\begin{array}{l}\text { Hemphill [43]; Twilley [44]; Breteler [45]; Cerónsouza } \\
\text { [46]; Cornejo [47]; Afzal [39] }\end{array}$ \\
\hline R. racemosa & $\begin{array}{l}\text { Nigeria; Ecuador; French Guiana; } \\
\text { Gambia; Senegal; Gabon; Togo; } \\
\text { America (Hawaii); Mexico }\end{array}$ & Ukoima [48]; Xavier [49]; Afzal [39]; Osorio [29] \\
\hline R. annamalayana & India & Elavarasi [50] \\
\hline R. samoensis & $\begin{array}{l}\text { Fiji (Viti Levu); America; Southwest } \\
\text { Pacific Islands (Caledonia, Hebrides); } \\
\text { Samoa; Marshall Islands }\end{array}$ & Tyagi [19]; Duke [51] \\
\hline
\end{tabular}

Table 1. The distribution of Rhizophora in the world.

endophytic Pestalotiopsis sp. is isolated and capable of producing lignin-degrading enzymes. This species secretes over 400 salt-adapted lignocellulolytic enzymes, which enhance the salt adaptation of mangrove hosts [18].

To date, the species of mangrove endophytic fungi identified from a large and diverse ecological group are mostly members of the Ascomycota phylum, with a limited occurrence of basidiomycetes [53, 54]. Since 1955, when Cribb first described endophytic fungi isolated from mangrove roots, several studies on the fungi residing in mangroves along the coastlines of the Indian, Pacific, and Atlantic Oceans have been conducted [55]. Hyde [56] listed approximately 120 fungal species that colonize 29 mangrove plants globally, including 87 ascomycetes, 31 mitosporic fungi, and 2 basidiomycetes. Schmit and Shearer [57, 58] reported 625 mangrove-associated fungi, including 279 ascomycetes, 277 mitosporic fungi, 29 basidiomycetes, 3 chytridiomycetes, 2 myxomycetes, 14 oomycetes, 9 thraustochytrids, and 12 zygomycetes. According to the frequency of their appearance, Alternaria, Aspergillus, Cladosporium, Colletotrichum, Fusarium, Paecilomyces, Penicillium, Pestalotiopsis, Phoma, Phomopsis, Phyllosticta, and Trichoderma have been recognized as the predominant culturable mangrove endophytic fungi [59]. 

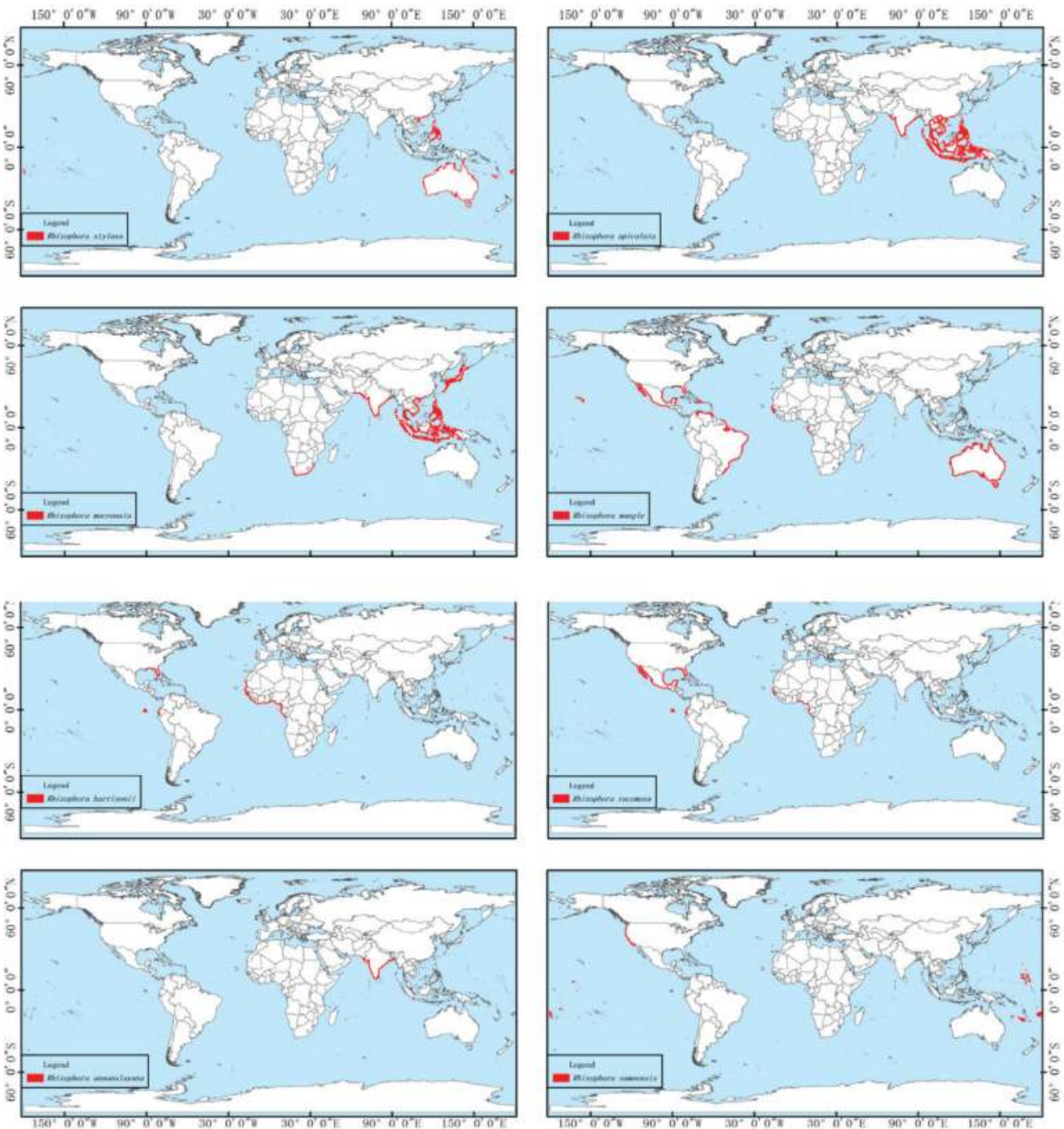

Figure 1. The distribution of Rhizophora in the world.

As a relatively underappreciated reservoir of bioresources, endophytic fungi from mangroves have been considered potential pharmaceutical and agricultural resources. Recent studies have investigated the biodiversity and distribution of mangrove endophytic fungi in the South China Sea. The taxonomic identities and diversity of endophytic fungal communities isolated from five species of the genus Sonneratia (S. caseolaris, S. hainanensis, S. ovata, S. paracaseolaris, and S. apetala) and four species of Rhizophoraceae (Ceriops tagal, R. apiculata, R. stylosa, and Bruguiera sexangula var. rhynchopetala) have been addressed [14].

Identification of biologically interesting metabolites from these endophytic fungi is an important initial step in understanding the role of endophytes to host mangrove plants. According 


\begin{tabular}{|c|c|c|c|}
\hline Plants species & Isolated endophytic fungi & $\begin{array}{l}\text { Sampling } \\
\text { location }\end{array}$ & Ref. \\
\hline \multirow[t]{5}{*}{ R. stylosa } & $\begin{array}{l}\text { Aureobasidium, Aspergillus, Cladosporium, Diaporthe, } \\
\text { Fusarium, Guignardia, Pestalotiopsis }\end{array}$ & China & Xing [14] \\
\hline & $\begin{array}{l}\text { Acremonium, Alternaria, Aspergillus, Bionectria, } \\
\text { Colletotrichum, Epicoccum, Nigrospora, Penicillium, } \\
\text { Pestalotiopsis, Phoma, Phomopsis, Phialophora, } \\
\text { Talaromyces, Trichoderma }\end{array}$ & & Hyde [60] \\
\hline & $\begin{array}{l}\text { Chaetomium, Corynespora, Fusarium, Geniculosporium, } \\
\text { Glomerella, Guignardia, Melanconium, Sphaceloma, } \\
\text { Pestalotiopsis, Phoma }\end{array}$ & & Liu [59] \\
\hline & Penicillium & Wen Chang & Peng [61] \\
\hline & Alternaria, Diaporthe, Mucor & Hainan & Gao [62];Zang [63];Sun [64] \\
\hline \multirow[t]{4}{*}{ R. apiculata } & $\begin{array}{l}\text { Aspergillus, Aureobasidium, Cladosporium, Diaporthe, } \\
\text { Fusarium, Massarina, Penicillium, Pestalotiopsis, } \\
\text { Phomopsis }\end{array}$ & $\begin{array}{l}\text { Dong Zhai } \\
\text { Gang }\end{array}$ & Xing [14]; \\
\hline & Acremonium, Flavodon, Phomopsis, Pestalotiopsis & Thailand & $\begin{array}{l}\text { Klaiklay [25];Klaiklay } \\
{[65,66] ; \text { Buatong }} \\
\text { [67];Rukachaisirikul, [26] }\end{array}$ \\
\hline & $\begin{array}{l}\text { Acremonium, Alternaria, Aureobasidium, Cladosporium, } \\
\text { Curvularia, Drechslera, Fusarium, Nodulisporium, } \\
\text { Pestalotiopsis, Phialophora, Phoma, Phomopsis, } \\
\text { Phyllosticta, Pithomyces, Glomerella, Sporothrix, } \\
\text { Sporormiella, Xylariaceous }\end{array}$ & India & Kumaresan [68] \\
\hline & $\begin{array}{l}\text { Acremonium, Alternaria, Cladosporium, Chaetomium, } \\
\text { Penicillium, Pestalotiopsis, Phialophora, Phoma, } \\
\text { Phyllosticta, Pseudeurotium, Sporormiella, Thielavia }\end{array}$ & & Suryanarayanan [31] \\
\hline \multirow[t]{6}{*}{ R. mucronata } & Pestalotiopsis & $\begin{array}{l}\text { Dong Zhai } \\
\text { Gang }\end{array}$ & $\mathrm{Xu}[69]$ \\
\hline & Aspergillus & Indonesia & Tarman [30] \\
\hline & Phomopsis & & Shiono [70] \\
\hline & Diaporthe, Neofusicoccum & South Africa & Osorio [29] \\
\hline & $\begin{array}{l}\text { Acremonium, Alternaria, Aspergillus, Botryotrichum, } \\
\text { Cladosporium, Chaetomium, Glomerella, Nigrospora, } \\
\text { Pestalotiopsis, Phialophora, Phomopsis, Phyllosticta, } \\
\text { Sporormiella, Trichoderma }\end{array}$ & India & Suryanarayanan [31] \\
\hline & $\begin{array}{l}\text { Ascotricha, Aspergillus, Cirrenalia, Cladosporium, } \\
\text { Dicyma, Fusariella, Paecilomyces, Penicillium, Phoma, } \\
\text { Phomopsis, Trichocladium, Zalerion, Zygosporium }\end{array}$ & & Ananda [71] \\
\hline \multirow[t]{4}{*}{ R. mangle } & Glomerella, Guignardia, Nodulisporium, Phyllosticta & Brazil & Wanderley [40] \\
\hline & Leucostoma & & Beau [72] \\
\hline & $\begin{array}{l}\text { Botryosphaeria, Colletotrichum, Coprinellus, Cytospora, } \\
\text { Diaporthe, Endothia, Epicoccum, Fusarium, Gibberella, } \\
\text { Glomerella, Guignardia, Hypocrea, Leptosphaeria, } \\
\text { Neofusicoccum, Penicillium, Phomopsis, Pichia, } \\
\text { Trichoderma, Xylaria, Valsa }\end{array}$ & & Sebastianes [73] \\
\hline & Cytospora & & Wier [74] \\
\hline
\end{tabular}




\begin{tabular}{llll}
\hline Plants species & Isolated endophytic fungi & $\begin{array}{l}\text { Sampling } \\
\text { location }\end{array}$ & Ref. \\
\hline R. harrisonii & Pestalotiopsis & Nigeria & Hemphill [43] \\
R. racemosa & Aspergillus, Lasiodiplodia, Paecilomyces, Penicillium & Nigeria & Ukoima [48] \\
R. annamalayana & Fusarium & Vellar estuary & Elavarasi [50] \\
R. samoensis & & & \\
\hline
\end{tabular}

Table 2. The endophytic fungi isolated from Rhizophora.

to the previous studies, the identification and phylogenetic diversity of mangrove endophytic fungi was largely associated with mangroves located in China, Thailand, Indonesia, Brazil, and India. In total, 26 genera of mangrove endophytic fungi were isolated from $R$. stylosa; 27 genera were isolated from $R$. apiculata; 26 genera were obtained from $R$. mucronata; 23 genera were isolated from $R$. mangle; 1 genus was isolated from $R$. harrisonii and $R$. annamalayana (namely Pestalotiopsis and Fusarium); and 4 genera of endophytic fungi were isolated from $R$. racemosa. Until now, no studies have been conducted on $R$. samoensis. In comparison with the previous reports, the frequently occurring fungi entophytes in Rhizophora, including 41 families and 64 genera belonging to 23 taxonomic orders of Ascomycota have been reported. The fungi of Basidiomycota are rarely found in Rhizophora. The dominant endophytic fungi of the Rhizophora genus are mainly distributed in Aspergillus, Cladosporium, Chaetomium, Fusarium, Lasiodiplodia, Penicillium, Pestalotiopsis, Phomopsis, Phoma, Phyllosticta, and Trichoderma (Table 2).

\section{The secondary metabolites of endophytic fungi of Rhizophora}

There is a wide range of endophytic fungi in mangroves, and their growing environment is unique. Thus, in the formation of special fungal communities, they will certainly metabolize compounds with rich structures, unlike that of terrestrial fungi. Many of these metabolites provide a rich model structure for the screening of new drugs, which have become increasingly valuable in drug-lead research [5]. A total of 195 metabolites were discovered from Rhizophora-derived endophytic fungi reported so far are included. The secondary metabolites of endophytic fungi of mangrove are classified as alkaloids, terpenes, coumarins, chromones, quinones, anthraquinones, peptides, phenolic acids, lactones, and other compounds.

\subsection{Alkaloids}

Fusariumequisetin AGR12 from R. stylosa produced two cyclicacetyl phytotoxin derivatives, equisetin(1) and epi-equisetin (2) [75,76]. Bothequisetin(1) and epi-equisetin (2) exhibitmodest antibacterial activity, and equisetin (1) had selective antimicrobial activity against some Gram-positive bacteria [77]. The metabolite equisetin was first purified from maize grit medium cultures of F. equiseti strain NRRL 5337, and equisetin can inhibit the ATPase activity of mitochondria in rat hepatocytes induced by 2,4-dinitrophenol (DNP) in a concentration-dependent manner. 
At a concentration of $8 \mathrm{nmol}$ equisetin/mg protein, the inhibition rate can reach $50 \%$ [78]. New cerebroside lipids, chrysogesides A-E (3-8), and new pyridone ketones, chrysogedones A and B $(9,10)$, were isolated from the fermentation extract of Penicillium chrysogenum PXP-55, isolated from $R$. stylosa. Compound (6) exhibited inhibitory activity against Enterobacter aerogenes with MIC value of $1.72 \mu \mathrm{M}$ [61]. The fungus species Pestalotiopsis JCM2A4, isolated from the Chinese mangrove plant Rhizophora mucronata, is one of the most abundant resources for screening natural products with different biological activities [79]. New N-substituted amide derivatives, pestalotiopamides A-E (12-16), and a new succinimide, pestalotiopsoid A (11), were isolated from the fermented crude extracts of Pestalotiopsis sp. JCM2A4, which was collected from $R$. mucronata [69, 80, 81]. A culture of the fungus Aspergillus nidulans MA-143, isolated from $R$. stylosa leaves, yielded six new compounds, and all the compounds contained the structural unit 4-phenyl-3,4-dihydroquinolin-2(1H)-one, aniduquinolones A-C (17-19), 6-deoxyaflaquinolone E (20), isoaflaquinolone E (21), 14-hydroxyaflaquinolone F (22), and aflaquinolone A (23). The bioactivity results showed that compounds 17-23 had no inhibitory activity against human hepatocellular carcinoma BEL-7402, breast cancer cell MDA-MB-231, leukemia myeloid cell HL-60, or chronic myeloid leukemia cell K652. Additionally, these compounds had no antibacterial activity against Staphylococcus aureus or Escherichia coli. Compounds 17, 19, and 23 exhibited lethal activity against Artemia salina, with $\mathrm{LD}_{50}$ values of 7.1, 4.5, and $5.5 \mu \mathrm{M}$, respectively [82]. About 6 new indole diterpenoid alkaloid derivatives (24-29) and 5 known similar metabolites, including 21-isopentenylpaxilline (30), paxilline (31), ehydroxypaxilline (32), emindole (33), and paspaline (34), were identified from a culture of Penicillium camemberti OUCMDZ-1492, isolated from the R. apiculata. Among them, compounds 24, 26-28, and 30-33 all showed strong H1N1 influenza virus inhibitory activity, with $\mathrm{IC}_{50}$ values ranging from 6 to $80 \mu \mathrm{M}$ [83]. A new paspaline (34) and three known analogs, penijanthine A (35), paspalinine (36), and penitrem (37), were isolated from Alternaria tenuissima EN-192 from $R$. stylosa stems. Compounds 34-37 had slight antimicrobial activity against Staphylococcus aureus, Escherichia coli, Bacillus subtilis, and Vibrio anguillarum [64]. The cultivable Phomopsis sp. PSU-MA214 from R. apiculata leaves can produce phenylethanol compounds, including phomonitroester (38). Compound 38 was initially isolated from Phomopsis sp. PSU-D15, which was from another plant of Garcinia dulcis [84]. The bioassay test showed that compound 38 had a weak inhibitory effect on breast cancer cells MCF-7 and KB85. The four new quinazolone alkaloid derivatives, aniquinazolines A-D (39-42) which were isolated from Aspergillus nidulans MA-143 in R. stylosa, showed strong lethal activity in shrimp, with $\mathrm{LD}_{50}$ values of $1.27,2.11,4.95$, and $3.42 \mu \mathrm{M}$, respectively. Meanwhile, they had no inhibitory activity against hepatoma cell BEL-7402, breast cancer cell MDA-MB-231, leukemia myeloid cell HL-60, and chronic myeloid leukemia cell K562. Moreover, no antibacterial activity against Staphylococcus aureus and Escherichia coli was observed [82]. Two new indole alkaloids, penioxamide A (43) and 18-hydroxydecaturin B (44), and a known compound decaturin B (45) were isolated from the fermented rice extract of $R$. stylosa endophytic fungi Penicillium oxalicum EN-201 [85]. Mucor irregularis QEN-189 was isolated from $R$. stylosa, from which 6 indole diterpenoid alkaloid derivatives and 14 analogs were separated, namely rhizovarins A-F (4650, 53), secopentrem D (51), PC-M4 (52), penijianthine A (54), penitrem A-F (55-60), paxilline (61), 27-O-acetylpaxillin (62), 13-deoxy-27-O-acetylpaxillin (63), 10-deoxy-13-deoxypaxilline 
(64), and 10ß-hydroxy-13-desoxypaxilline (65). As for antitumor activity, compounds 46, 47, $50,55,57,60$, and 65 had inhibitory activity against lung cancer cell A549, and the $\mathrm{IC}_{50}$ values were $11.5,6.3,9.2,8.4,8.0,8.2$, and $4.6 \mu \mathrm{M}$, respectively. They also had inhibitory activity against leukemia cells of HL-60, with $\mathrm{IC}_{50}$ values of 9.6, 5.0, 7.0, 4.7, 3.3, and $2.6 \mu \mathrm{M}$, respectively [62]. The Hypocrea virens of R. apiculata is capable of producing isoquinoline alkaloids, 2-methylimidazo[1,5-b]isoquinoline-1,3,5(2H)-trione (66) [86] (Figure 2).

\subsection{Terpenoids}

A new sesquiterpene, diaporol A (67), with a tricyclic lactone structure; eight new sesquiterpenes, diaporols B-I (68-75); drimane; $3 \beta$-hydroxyconfertifolin (76); and diplodiatoxin (77) were isolated from Diaporthe sp. of $R$. stylosa. The bioactivity test showed that compounds 67-77 had no cytotoxicity on human gastric cancer cell SGC-7901, breast cancer cell MCF-7, lung cancer cell A549, and hepatocellular carcinoma cell line QGY-7701 at a concentration of $20 \mu \mathrm{M}$ [63]. Flavodon flavus PSU-MA201 was isolated from $R$. apiculata, from which a known perhydroazulene compound, tremulenolide A (78), was separated, and the bioassay test showed that compound $\mathbf{7 8}$ exhibited modest antibacterial activity against Staphylococcus aureus ATCC25923 and Cryptococcus neoformans ATCC90113 with MIC values of $128 \mu \mathrm{g} /$ $\mathrm{mL}[65,66]$. A known altiloxin B (79) with drimane was isolated from Pestalotiopsis sp. of R. mucronata [87]. Two known mycotoxins, 8-deoxytrichothecin (80) and trichodermol (81), were isolated from the Acremonium sp. PSU-MA70 of $R$. apiculata [26]. As a plant-derived anticancer drug with a unique mechanism, taxol (82) was isolated from Taxus brevifolia bark and wood for the first time by American chemists Wani and Wall in 1963 [88, 89]. Subsequently, it has been found that endophytic fungi Taxomyces [90], Pestalotiopsis [91], Alternaria [92], and Fusarium [93] could also produce taxol and its analogs. Taxol (82) was also isolated from endophytic fungus Fusarium oxysporum in R. annamalayana [50]. Two new compounds, pestalotiopens A and B $(\mathbf{8 3}, \mathbf{8 4})$, were separated from the Pestalotiopsis sp. JCM2A4 from leaves of $R$. mucronata, and the bioactivity assay revealed that compound 83 was slightly

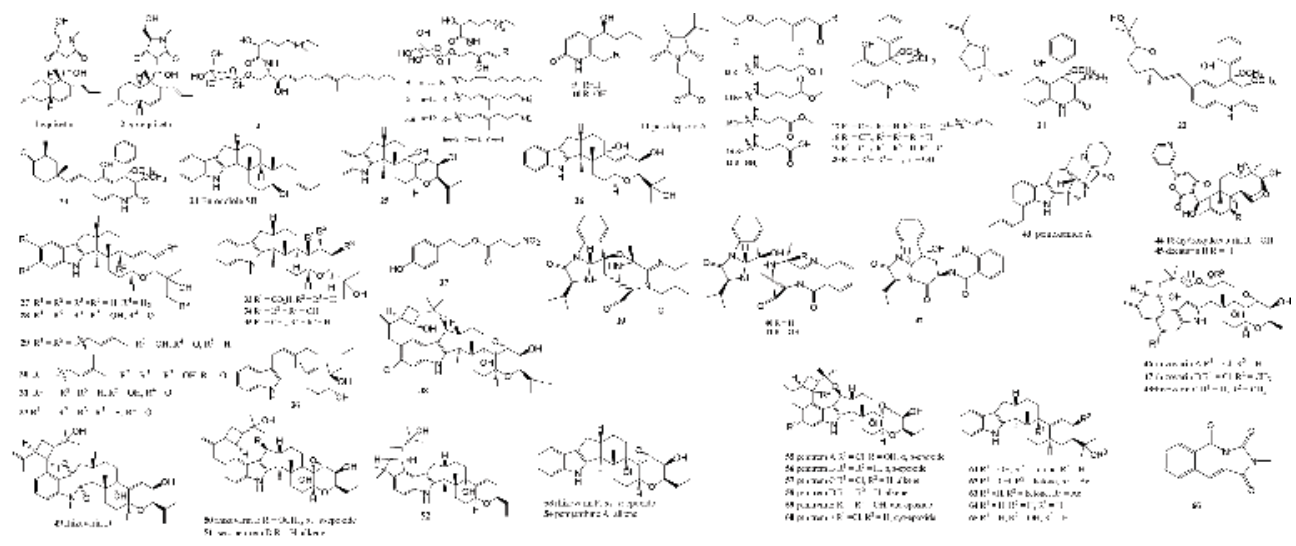

Figure 2. The structures of alkaloids in Rhizophora-derived endophytic fungi. 
resistant to Staphylococcus aureus, Escherichia coli, Enterococcus faecalis, Streptococcus pyogenes, Pseudomonas aeruginosa, and Klebsiella pneumoniae, with the MIC values ranging from 125 to $250 \mu \mathrm{M}[87]$ (Figure 3).

\subsection{Coumarins}

A strain of Pestalotiopsis sp. was isolated from the leaves of R. mucronata, which is an important resource of coumarin compounds. Pestalasins A-E (85-89) and one known compound, 3-dydroxymethyl-6,8-dimethoxycoumarin (90), were separated from fermentation extracts, and this was the first time that coumarin had been found in the mangrove microbes [69]. A more in-depth study of the chemical constituents of Pestalotiopsis sp. led to the discovery of a new isocoumarin derivative, pestalotiopisorin A (91) [80]. Seven new structural analogs, acremonones B-H (92-98), were isolated from Acremonium sp. PSU-MA70, which was from R. apiculata [26]. Pestalotiopsis clavispora was isolated from the leaves of $R$. harrisonii, and four new polyketide derivatives were separated from endophytic fungi, including pestapyrones A-C (99-101), (R)-periplanetin D (103), and similanpyrone B (102) [43] (Figure 4).

\subsection{Chromones}

Three rare chlorinated chromone derivatives, pestalochromones A-C (104-106), were isolated from Pestalotiopsis sp. PSU-MA69 in R. apiculata [25]. Further studies on the chemical composition of Pestalotiopsis sp. from $R$. mucronata led to the discovery of a series of rare lipophilic chromone derivatives, pestalotiopsones A-F (107-112), and the known compound, 5-carbomethoxymethyl-heptyl-7-hydroxychromone (113). The bioactivity test showed that compound $\mathbf{1 1 1}$ had weak cytotoxic activity against mouse lymphoma cell L5178Y, with an $\mathrm{EC}_{50}$ value of $29.4 \mu \mathrm{M}$ [69]. Four new chromone derivatives, phomopsichins A-D (114-117), along with a known compound, phomoxanthone $\mathrm{A}$ (118), were isolated from the fermentation products of Phomopsis sp. $33^{\#}$ from $R$. stylosa. The bioassay results showed that compounds

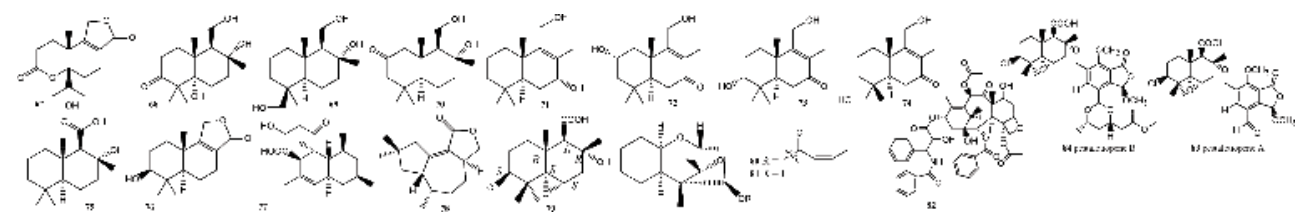

Figure 3. The structures of terpenoids in Rhizophora-derived endophytic fungi.
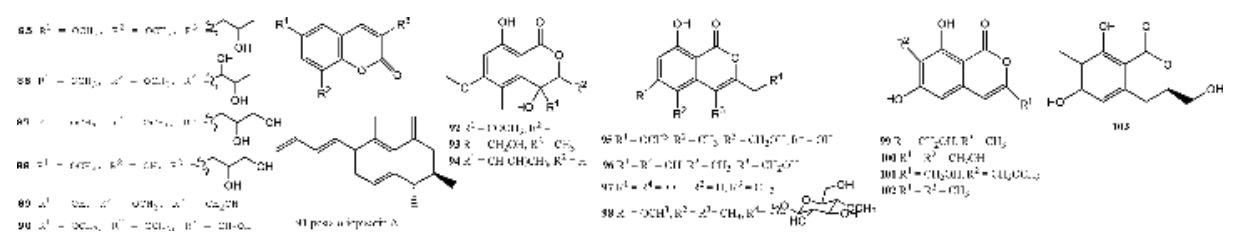

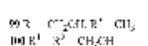

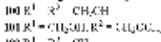
111 $\mathrm{CH}^{1 \mathrm{~m}}$

Figure 4. The structures of coumarins in Rhizophora-derived endophytic fungi. 
114-118 had weak inhibitory effects on acetylcholinesterase (AchE), $\alpha$-glucanase, DPPH radical and hydroxyl radical, as well as weak inhibitory activity against 18 kinds of plant pathogenic bacteria [94]. A new polyketone derivative, pestalpolyol I (119), was isolated from Pestalotiopsis clavispora in R. harrisonii. The bioactivity test showed that compound $\mathbf{1 1 9}$ had strong inhibitory activity against tumor cells L5178Y, with an $\mathrm{IC}_{50}$ value of $4.1 \mu \mathrm{M}$. Compound 119 also showed inhibitory activity against leukemia myeloid cells HL-60, hepatoma cells SMMC-7721, lung cancer cells A-549, breast cancer cells MCF-7, and human colon cancer cells SW480, with $\mathrm{IC}_{50}$ values of 10.4, 11.3, 2.3, 13.7 and $12.4 \mu \mathrm{M}$, respectively [43] (Figure 5).

\subsection{Anthraquinones}

One new tetrahydroanthraquinone derivative, (2R, 3S)-7-ethyl-1,2,3,4-tetrahydro-2,3,8trihydroxy-6-methoxy-3-methyl-9,10-anthracenedione (120) and five known anthraquinones derivatives (121-125) were isolated from the endophytic fungi Phomopsis sp. PSU-MA214 from $R$. apiculata leaves. Compound $\mathbf{1 2 0}$ had the structure of ethyl tetrahydroanthraquinone, which was weakly cytotoxic to human breast cancer cell MCF-7 and had antibacterial activity against Staphylococcus aureus ATCC25923 and methicillin-resistant S. aureus SK1 [25]. Three known tricyclic alternarene derivatives (126-128) were isolated from the endophytic fungus Alternaria tenuissima EN-192 from $R$. stylosa branches, and the antimicrobial activity, tested by filter paper diffusion method, showed that compound $\mathbf{1 2 6}$ had moderate antibacterial activity against Vibrio anguillarum [64]. One new xanthone, pestaloxanthone (129), was isolated with two known analogs, isosulochrin dehydrate (130) and chloroisosulochrin dehydrate (131), from endophytic fungi Pestalotiopsis sp. PUS- MA69 from $R$. apiculata branches [25]. A known tetrahydrogenated xanthanone dimer, phomoxanthone A (132), and a new compound with similar structure, 12-O-deacetyl-phomoxanthone A (133), were isolated from a rice fermentation culture extract of the fungus Phomopsis sp. IM 41-1 from R. mucronata. Two compounds $(\mathbf{1 3 2}, \mathbf{1 3 3})$ had weak antibacterial activity against Botrytis cinerea, Sclerotinia aureus, Diaporthe medusaea, and Staphylococcus aureus, while acetylation of the compound had no significant effect on the antimicrobial activity [70]. A known compound, pestaxanthone (134), was isolated from Pestalotiopsis clavispora from the leaves of the genus R. harrisonii [43] (Figure 6).

\subsection{Peptides}

Four known compounds, two ring-phthalocyanines, guangomides A and B $(\mathbf{1 3 5}, \mathbf{1 3 6})$, and two diketopiperazine derivatives, Sch 54794 and Sch $54796(137,138)$, were isolated from the
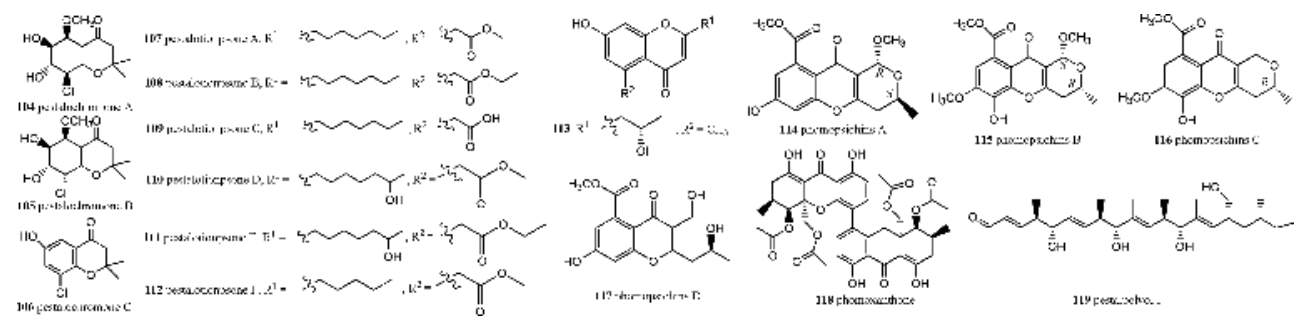

Figure 5. The structures of chromones in Rhizophora-derived endophytic fungi. 


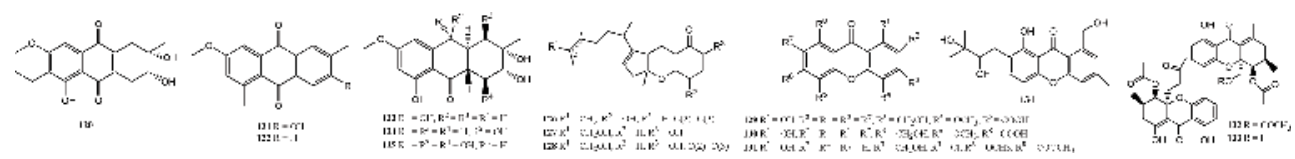

Figure 6. The structures of anthraquinones in Rhizophora-derived endophytic fungi.

Acremonium sp. PSU-MA70 from R. apiculata [26]. Activity tests showed that compounds $\mathbf{1 3 5}$ and $\mathbf{1 3 6}$ had weak antibacterial activity against Staphylococcus epidermidis and Enterococcus durans [95] (Figure 7).

\subsection{Phenolics}

In this category, four new diphenyl ether compounds, pestalotethers A-D (141, 143-145), and three known compounds, pestheic acid (142), chloroisosulochrin (139), and isosulochrin (140), were isolated from Pestalotiopsis sp. PSU-MA69 of R. apiculata [25]. A new compound, norpestaphthalide A (146), and three known compounds, (R, S)-5,7-dihydroxy-3-(1-hydroxyethyl) phthalide (148) and pestaphthalides A and B $(\mathbf{1 4 7}, \mathbf{1 4 9})$, were isolated from Pestalotiopsis clavispora in the leaves of $R$. harrisonii. These compounds had no inhibitory effect on leukemia myeloid cells HL-60, hepatoma cells SMMC-7721, lung cancer cells A-549, breast cancer cells MCF-7, and human colon cancer cells SW480 [43] (Figure 8).

\subsection{Lactones}

Five new compounds, including cytosporones J-N (152-156), together with known metabolites, dothiorelones A (150) and cytosporones C (151), were isolated from the Pestalotiopsis sp. from R. mucronata. Biological tests showed that compound $\mathbf{1 5 0}$ was cytotoxic to human oral epidermoid carcinoma KB cells, lymphoma cells Raji, and human osteosarcoma cells Mg-63. Compounds 151-156 had no significant antitumor activity [69]. In the further study of Pestalotiopsis sp. of $\mathrm{R}$. mucronata, eight new pyrone compounds, pestalotiopyrones A-H

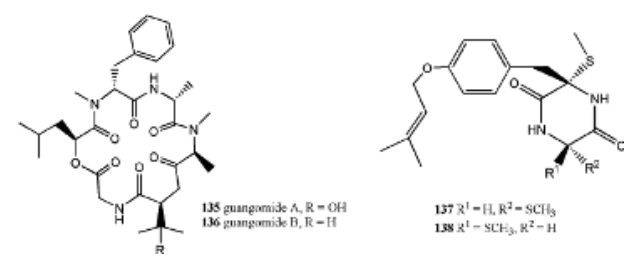

Figure 7. The structures of peptides in Rhizophora-derived endophytic fungi.

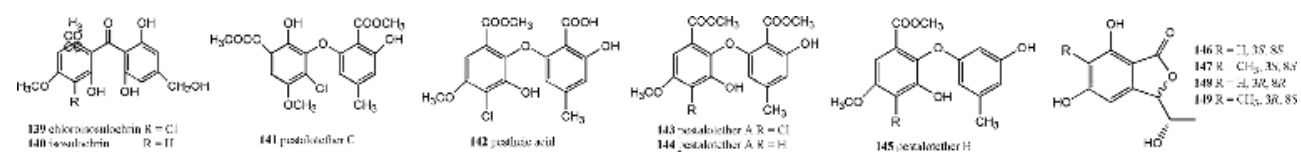

Figure 8. The structures of phenolics in Rhizophora-derived endophytic fungi. 
(157-164); two new compounds, pestalotiollides A and B $(166,167)$; and one known compound, nigrosporapyrone D (165), were found in large amounts of fermentation products in the rice culture medium [80]. Three new $\alpha$-pyrone pestalotiopyrones A-C (168-170); two new seiricuprolide macrolides, pestalotioprolides A (171) and B (173); and two known compounds, seiricuprolide (174) and 2'-hydroxy-3',4'-didehydropenicillide (172), were isolated from two endophytic fungi Pestalotiopsis sp. PSU-MA92 and Pestalotiopsis sp. PSU-MA119 of $R$. apiculata and R. mucronata [96]. Among these, compounds 168-170 were repetitive names of pestalotiopyrones A-C [80]. Thus far, the carbon skeleton of phenyleol lactones has been rarely found among natural products [97]. One new butenolactone, pestalolide (175), and one known phytotoxin, seiridin (176), were found in the fermentation product of endophytic fungi pestalotiopyrones sp. PSU-MA69, which was from $R$. apiculata. The bioactivity analysis showed that compound 175 had weak antimicrobial activity against Candida albicans and Cryptococcus neoformans, with MIC values of $653.06 \mu \mathrm{M}$ [25]. A new phthalic acid derivative, acremonide (177), and one new depsidone, acremonone A (179), together with two known substances, (+)-brefelin A (180) and 5,7-dimethoxy-3,4-dimethyl-3-hydroxyphthalide (178), were separated from the Acremonium sp. PSU-MA70, which was isolated from $R$. apiculata [26]. Brefelin A (BFA) is a fungal metabolite that was originally used as an antiviral agent and is now primarily used to study protein transport. It can specifically and reversibly inhibit the Golgi membrane protein protease, prohibiting the linkage of guanine nucleotides to ADP ribosylation factor and, therefore, preventing the transport of proteins from the endoplasmic reticulum (ER) to the Golgi. BFA is also used to inhibit the secretion of cytokine and other proteins as well as enhance the immunostaining of secretory proteins. BFA can activate the neural sheath phosphoric acid cycle, inducing the apoptosis of some tumor cells [98], and it has a weak antibacterial activity against Candida albicans NCPF3153 [26]. Three known substances, macrolides pestalotiollides A and B $(\mathbf{1 8 1}, \mathbf{1 8 2})$ and 2-epi-herbarumin II (183), were isolated from the fermentation extract of Pestalotiopsis clavispora from $R$. harrisonii. Bioactivity tests showed that compounds 181-183 had no antitumor effect on leukemia myeloid cells HL-60, hepatoma cell SMMC-7721, lung cancer cell line A-549, breast cancer cell MCF-7, or human colon cancer cell SW480 [43]. In order to effectively control the biosynthesis of Leucostoma persoonii from $R$. mangle and stimulate the production of cytosporone compounds, a known antibacterial trihydroxy lactone compound, cytosporone E (184), was induced by epigenetic modification [72]. Compound $\mathbf{1 8 4}$ showed a strong anti-infective activity against Plasmodium falciparum with an $\mathrm{IC}_{50}$ value of $13 \mu \mathrm{M}$. Additionally, compound $\mathbf{1 8 4}$ showed strong inhibitory activity against human lung cancer cell A549, with an IC50 value of $437 \mu \mathrm{M}$, and a strong inhibitory effect on methicillin-resistant S. aureus, with an MIC value of $72 \mu \mathrm{M}$ [97] (Figure 9).

\subsection{Others}

A new difuranylmethane-derived furan fatty acid, flavodonfuran (185), was isolated from the endophytic fungus Flavodon flavus PSU-MA201 from R. apiculata [65, 66]. Xu isolated a new enoic acid compound, pestalotiopin A (187), and two known compounds, 2-anhydromevalonic acid (186) and p-hydroxybenzaldehyde (188), from the Pestalotiopsis sp. of R. mucronata [80]. Rukachaisirikul and coworkers isolated two known compounds, 4-methyl-1-phenyl2,3-hexanediol (189) and (2R,3R)-4-methyl-1-phenyl-2,3-pentanediol (190), from the Acremonium sp. PSU-MA70 of R. apiculata [26]. One known phenylethanol propionate (191) and a known butanamide compound, butanamide (192), were isolated from the endophytic fungus Phomopsis 


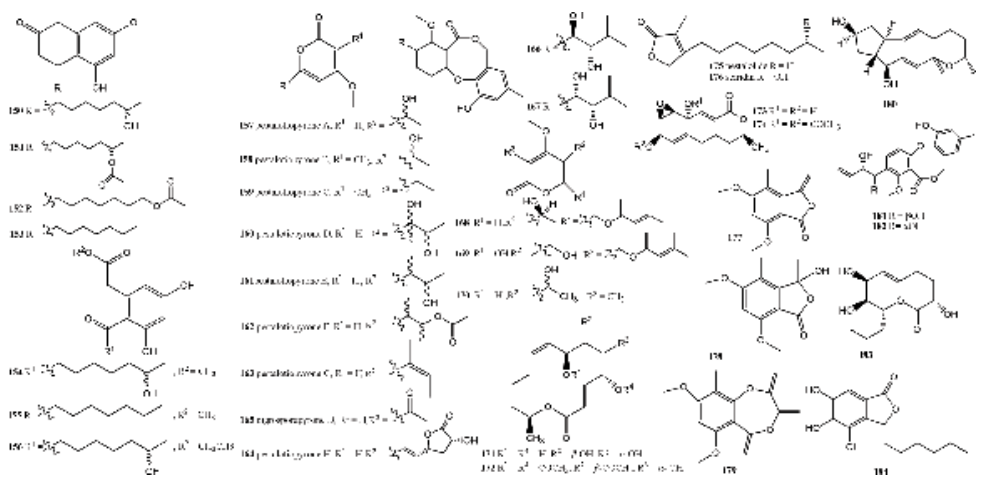

Figure 9. The structures of lactones in Rhizophora-derived endophytic fungi.
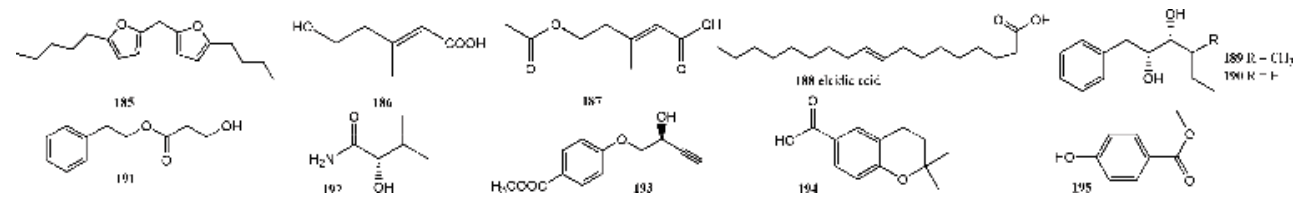

Figure 10. The structures of others in Rhizophora-derived endophytic fungi.

sp. PSU-MA214 from $R$. apiculata [25]. (S)-penipratynolene (193), DNA-damaging active anofinic acid (194), and $p$-hydroxybenzoic acid methyl ester (195) were isolated from Pestalotiopsis sp. PSU-MA69 of R. apiculata [25] (Figure 10).

\section{Conclusion}

In this review, we summarize the distribution of frequently occurring fungal endophytes in Rhizophora: 26 genera of mangrove endophytic fungi were isolated from $R$. stylosa; 27 genera were isolated from $R$. apiculata; 26 genera were obtained from $R$. mucronata; 23 genera were isolated from $R$. mangle; 1 genus was isolated from $R$. harrisonii and $R$. annamalayana (namely Pestalotiopsis and Fusarium); and 4 genera of endophytic fungi were isolated from $R$. racemosa. Until now, no studies have been conducted on $R$. samoensis. In total, the frequently occurring fungi entophytes in Rhizophora, including 41 families and 64 genera belonging to 23 taxonomic orders of Ascomycota have been reported. Although the biological potential of endophytic fungi from the abovementioned Rhizophora species has not been thoroughly investigated, the core group of fungi can be recognized from different geographic locations. The distribution and molecular phylogeny of the fungi are discussed as well as new findings regarding the chemistry and bioactivity of natural products found in Rhizophora endophytic fungi. The Pestalotiopsis, Penicillium, and Mucor genera of endophytic fungi were identified as the most promising fungal groups in terms of chemical diversity. In particular, the Pestalotiopsis genus constituted $42.56 \%$ of the compounds reported, as shown in Figure 11. R. apiculata (34.36\%) was observed to be the most investigated host plant, followed by R. stylosa (33.85\%) and R. mucronata (23.59\%). The chemical identification of metabolites of $R$. racemosa endophytic fungi has not yet been reported (Figure 11). 

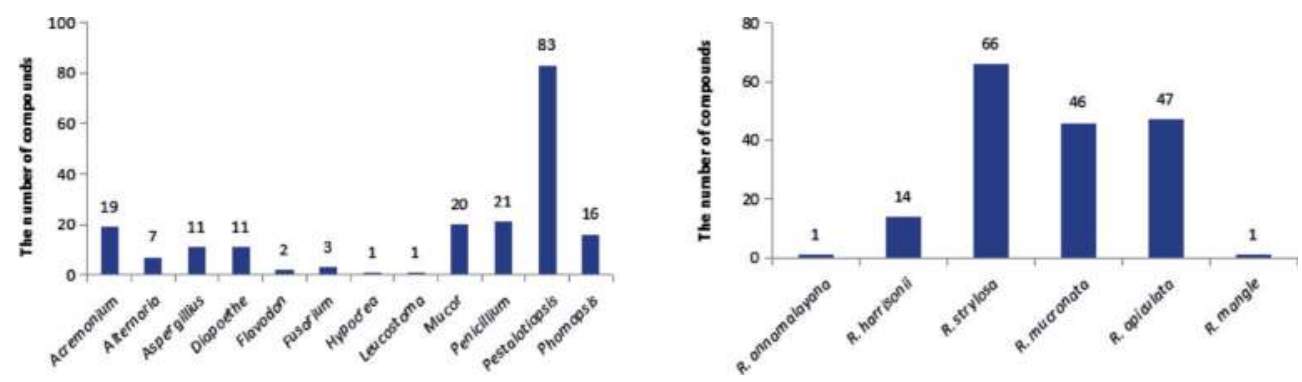

Figure 11. Comparison of metabolite distributions by mangrove endophytic fungal and host Rhizophora species.

Some secondary metabolites with unusual structures were identified in Rhizophora endophytic fungi. Novel hybrid sesquiterpene-cyclopaldic acid metabolites with unusual carbon skeletons, pestalotiopens A and B $(\mathbf{8 3}, \mathbf{8 4})$, were obtained from the endophytic fungus Pestalotiopsis sp. JCM2A4 isolated from the leaves of the Chinese mangrove, $R$. mucronata. Bioassays revealed that antitumor, antimicrobial, and anti-H1N1 activities are the most notable bioactivities of the secondary metabolites from Rhizophora endophytic fungi. Some compounds had significant bioactivities, as exemplified by pestalpolyol 1 (119), a novel polyketone derivative isolated from $P$. clavispora. Compound $\mathbf{1 1 9}$ has a strong inhibitory effect on mouse lymphoma cell line L5178Y with an $\mathrm{IC}_{50}$ value of $4.10 \mu \mathrm{M}$. The indole diterpene alkaloids, rhizovrin $\mathrm{A}, \mathrm{B}$, and $\mathrm{F}$ $(46,47,50)$, isolated from endophytic fungi Mucor irregularis QEN-189, have strong inhibitory effects on lung cancer cells A549, with $\mathrm{IC}_{50}$ values of $11.5,6.3$, and $9.2 \mu \mathrm{M}$, respectively, as well as inhibitory effects on leukemia myeloid cells HL-60, with $\mathrm{IC}_{50}$ values of 9.6, 5.0, and $7.0 \mu \mathrm{M}$, respectively. These findings suggest that Rhizophora endophytic fungi offering numerous useful products with medicinal and pathogenic significance have yet to be established.

\section{Acknowledgements}

This study was funded by grants from the National Natural Science Foundation of China (No. 81660584), Key Research Program of Hainan Province (ZDYF2017099), and the Innovative Research Team Grant of the Natural Science Foundation of Hainan University (hdkytg201705) and is gratefully acknowledged.

\section{Author details}

Jing Zhou and Jing $\mathrm{Xu}^{*}$

*Address all correspondence to: happyjing3@163.com

Key Laboratory of Tropical Biological Resources of Ministry of Education, College of Material and Chemical Engineering, Hainan University, Haikou, PR China 


\section{References}

[1] Debbab A, Aly AH, Proksch P. Mangrove derived fungal endophytes-A chemical and biological perception. Fungal Diversity. 2013;61:1-27. DOI: 10.1007/s13225-013-0243-8

[2] Hyde KD, Soytong K. The fungal endophyte dilemma. Fungal Diversity. 2008;33:163-173

[3] Strobel G, Daisy B. Bioprospecting for microbial endophytes and their natural products. Microbiology and Molecular Biology Reviews. 2003;67:491-502. DOI: 10.1128/ MMBR.67.4.491-502.2003

[4] Xu J. Biomolecules produced by mangrove-associated microbes. Current Medicinal Chemistry. 2011;18:5224-5266. DOI: 10.2174/092986711798184307

[5] Xu J. Bioactive natural products derived from mangrove-associated microbes. RSC Advances. 2015;5:841-892. DOI: 10.1039/c4ra11756e

[6] Aly AH, Debbab A, Kjer J, et al. Fungal endophytes from higher plants: A prolific source of phytochemicals and other bioactive natural products. Fungal Diversity. 2010;41:1-16. DOI: $10.1007 / \mathrm{s} 13225-010-0034-4$

[7] Giri C, Ochieng E, Tieszen LL, et al. Status and distribution of mangrove forests of the world using earth observation satellite data. Global Ecology and Biogeography. 2011;20:154-159. DOI: 10.1111/j.1466-8238.2010.00584.x

[8] Wang Y, Zhu H, Tam NFY. Polyphenols, tannins and antioxidant activities of eight true mangrove plant species in South China. Plant and Soil. 2014;374:549-563. DOI: 10.1007/ s11104-013-1912-9

[9] Ye F, Li XW, Guo YW. Recent progress on the mangrove plants: Chemistry and bioactivity. Current Organic Chemistry. 2016;20:1923-1942. DOI: 10.2174/1385272820666160421 151209

[10] Wu J, Xiao Q, Xu J a. Natural products from true mangrove flora: Source, chemistry and bioactivities. Natural Product Reports. 2008;25:955-981. DOI: 10.1039/b807365a

[11] Chen L, Wang W, Zhang Y, et al. Recent progresses in mangrove conservation, restoration and research in China. Journal of Plant Ecology. 2009;2:45-54. DOI: 10.1097/ 00019052-200502000-00004

[12] Yang XB. Hainan Plant Flora. 1st ed. Vol. IV. Beijing: Science Press; 2015. pp. 262-271

[13] Lo EY, Duke NC, Sun M. Phylogeographic pattern of Rhizophora (Rhizophoraceae) reveals the importance of both vicariance and long-distance oceanic dispersal to modern mangrove distribution. BMC Evolutionary Biology. 2014;14:83-98. DOI: 10.1186/ 1471-2148-14-83

[14] Xing X, Guo S. Fungal endophyte communities in four Rhizophoraceae mangrove species on the south coast of China. Ecological Research. 2011;26:403-409. DOI: 10.1007/ s11284-010-0795-y 
[15] Villamayor BMR, Rollon RN, Samson MS, et al. Impact of Haiyan, on Philippine mangroves: Implications to the fate of the widespread monospecific Rhizophora, plantations against strong typhoons. Ocean and Coastal Management. 2016;132:1-14. DOI: 10.1016/j. ocecoaman.2016.07.011

[16] Dangan-Galon F, Dolorosa RG, Sespeñe JS, et al. Diversity and structural complexity of mangrove forest along Puerto Princesa Bay, Palawan Island, Philippines. Journal of Marine and Island Cultures. 2016;5:118-125. DOI: 10.13140/RG.2.2.14885.70887

[17] Morton B. Hong Kong's mangrove biodiversity and its conservation within the context of a southern Chinese megalopolis. A review and a proposal for Lai Chi Wo to be designated as a World Heritage Site. Regional Studies in Marine Science. 2016;8:382-399. DOI: org/10.1016/j.rsma.2016.05.001

[18] Arfi Y, Buée M, Marchand C, et al. Multiple markers pyrosequencing reveals highly diverse and host-specific fungal communities on the mangrove trees Avicennia marina and Rhizophora stylosa. FEMS Microbiology Ecology. 2011;79:433-444. DOI: 10.1111/ j.1574-6941.2011.01236.x

[19] Tyagi AP. Precipitation effect on flowering and propagule setting in mangroves of the family Rhizophoraceae. Australian Journal of Botany. 2004;52:789-798. DOI: 10.1071/ BT02077

[20] Kohlmeyer J. Marine fungi of Queensland, Australia. Marine and Freshwater Research. 1991;42:91-99. DOI: 10.1071/MF9910091

[21] Selvaraj G, Kaliamurthi S, Thirugnasambandan R. Effect of glycosin alkaloid from Rhizophora apiculata, in non-insulin dependent diabetic rats and its mechanism of action: In vivo, and in silico, studies. Phytomedicine International Journal of Phytotherapy and Phytopharmacology. 2016;23:632-640. DOI: 10.1016/j.phymed.2016.03.004

[22] Rossiana N, Miranti M, Rahmawati R. Antibacterial activities of endophytic fungi from mangrove plants Rhizophora apiculata L. and Bruguiera gymnorrhiza(L.) Lamk. on Salmonella typhi. Towards the Sustainable Use of Biodiversity in A Changing Environment: From Basic to Applied Research: Proceeding of the International Conference on Biological Science, Vol. 020040; 2016. pp. 1-6

[23] Clough B, Dang TT, Phuong DX, et al. Canopy leaf area index and litter fall in stands of the mangrove Rhizophora apiculata of different age in the Mekong Delta, Vietnam. Aquatic Botany. 2000;66:311-320. DOI: 10.1016/S0304-3770(99)00081-9

[24] Piapukiew J, Whalley AJS, Sihanonth P. Endophytic fungi from mangrove plant species of Thailand: Their antimicrobial and anticancer potentials. Botanica Marina. 2010;53: 555-564. DOI: 10.1515/bot.2010.074

[25] Klaiklay S, Rukachaisirikul V, Phongpaichit S. Anthraquinone derivatives from the mangrove-derived fungus Phomopsis sp. PSU-MA214. Phytochemistry Letters. 2012;5:738-742

[26] Rukachaisirikul V, Rodglin A, Sukpondma Y, et al. Phthalide and isocoumarin derivatives produced by an Acremonium sp. isolated from a mangrove Rhizophora apiculata. Journal of Natural Products. 2012;75:853-858. DOI: 10.1021/np200885e 
[27] Tan TK, Pek CL. Tropical mangrove leaf litter fungi in Singapore with an emphasis on Halophytophthora. Mycological Research. 1997;101:165-168. DOI: 10.1017/s095375 6296002250

[28] Trinh BT, Staerk D, Jäger AK. Screening for potential $\alpha$-glucosidase and $\alpha$-amylase inhibitory constituents from selected Vietnamese plants used to treat type 2 diabetes. Journal of Ethnopharmacology. 2016;186:189-195. DOI: 10.1016/j.jep.2016.03.060

[29] Osorio JA, Wingfield MJ, Roux J. A review of factors associated with decline and death of mangroves, with particular reference to fungal pathogens. South African Journal of Botany. 2016;103:295-301. DOI: 10.1016/j.sajb.2014.08.010

[30] Tarman K, Safitri D, Setyaningsih I. Endophytic fungi isolated from Rhizophora mucronata and their antibacterial activity. Squalen: Bulletin of Marine \& Fisheries Postharvest and Biotechnology. 2014;8:69-76

[31] Suryanarayanan TS, Kumaresan V, Johnson JA. Foliar fungal endophytes from two species of the mangrove Rhizophora. Canadian Journal of Microbiology. 1988;44:1003-1006. DOI: $10.1139 /$ cjm-44-10-1003

[32] Rani V, Sreelekshmi S, Preethy CM, et al. Phenology and litterfall dynamics structuring ecosystem productivity in a tropical mangrove stand on South West coast of India. Regional Studies in Marine Science. 2016;5:1-8. DOI: 10.1016/j.rsma.2016.02.008

[33] Kandasamy S, Kandasamy K. Antioxidant activity of the mangrove endophytic fungus (Trichoderma sp.). Journal of Coastal Life Medicine. 2014;2:559-563. DOI: 10.12980/ JCLM.2.2014JCLM-2014-0001

[34] Tariq M, Dawar S, Mehdi FS. Occurrence of fungi on mangrove plants. Pakistan Journal of Botany. 2006;38:1293-1299

[35] Boehm FR, Sandrini-Neto L, Moens T, et al. Sewage input reduces the consumption of Rhizophora mangle propagules by crabs in a subtropical mangrove system. Marine Environmental Research. 2016, 2016;122:23-32. DOI: 10.1016/j.marenvres.2016.09.003

[36] Ferreira AC, Lacerda LD. Degradation and conservation of Brazilian mangroves, status and perspectives. Ocean and Coastal Management. 2016;125:38-46. DOI: 10.1016/j. ocecoaman.2016.03.011

[37] Barreto MB, Mónaco SL, Díaz R, et al. Soil organic carbon of mangrove forests (Rhizophora, and Avicennia) of the Venezuelan Caribbean coast. Organic Geochemistry. 2016;100: 51-61. DOI: 10.1016/j.orggeochem.2016.08.002

[38] Ball MC. Patterns of secondary succession in a mangrove forest of Southern Florida. Oecologia. 1980;44:226-235. DOI: 10.1007/BF00572684

[39] Afzal-Rafii Z, Dodd RS, Fauvel MT. A case of natural selection in Atlantic-East-Pacific, Rhizophora. Hydrobiologia. 1999;413:1-9. DOI: 10.1023/A:1003882508994

[40] Wanderley CIP, Maia LC, Cavalcanti MA. Diversity of leaf endophytic fungi in mangrove plants of Northeast Brazil. Brazilian Journal of Microbiology. 2012;43:1165-1173. Presses Universitaires de France. DOI: 10.1590/S1517-838220120003000044 
[41] Dourado MN, Ferreira A, Araújo WL, et al. The diversity of endophytic methylotrophic bacteria in an oil-contaminated and an oil-free mangrove ecosystem and their tolerance to heavy metals. Biotechnology Research International. 2012;2012:1-8. DOI: $10.1155 / 2012 / 759865$

[42] Godoy MD, De LLD. Mangroves response to climate change: A review of recent findings on mangrove extension and distribution. Anais da Academia Brasileira de Ciências. 2015;87:651-667. DOI: 10.1590/0001-3765201520150055

[43] Hemphill CFP, Daletos G, Liu Z, et al. Polyketides from the mangrove-derived fungal endophyte Pestalotiopsis clavispora. Tetrahedron Letters. 2016;57:2078-2083. DOI: 10.1016/j. tetlet.2016.03.101

[44] Twilley RR, Pozo M, Garcia VH, et al. Litter dynamics in riverine mangrove forests in the Guayas River estuary, Ecuador. Oecologia. 1997;111:109-122. DOI: 10.1007/s0044 20050214

[45] Breteler FJ. The Atlantic species of Rhizophora. Acta Botanica Neerlandica. 1969;18:434-441. DOI: 10.1111/j.1438-8677.1969.tb00607.x

[46] Cerónsouza I, Riveraocasio E, Medina E, et al. Hybridization and introgression in New World red mangroves, Rhizophora (Rhizophoraceae). American Journal of Botany. 2010;97:945-957. Source: PubMed. DOI: 10.3732/ajb.0900172

[47] Cornejo X. Lectotypification and a new status for Rhizophora $\times$ harrisonii (Rhizophoraceae), a natural hybrid between R. mangle and R. racemosa. Harvard Papers in Botany. 2013; 18:37-38. DOI: $10.3100 / 025.018 .0106$

[48] Ukoima HN, Ikata M. Mycoparasitism on some fungal isolates of Rhizophora racemosa Linn. American Journal of Scientific Research. 2013;84:139-144

[49] Xavier C, Carmen B. Rhizophora racemosa G. Mey (Rhizophoraceae) en Ecuador y Perú, y el color de los óvulos: un nuevocaracter en Rhizophora. Brenesia. 2006;65:11-17. DOI: 10.3100/025.018.0106

[50] Elavarasi A, Rathna GS, Kalaiselvam M. Taxol producing mangrove endophytic fungi Fusarium oxysporum, from Rhizophora annamalayana. Asian Pacific Journal of Tropical Biomedicine. 2012;2:S1081-S1085

[51] Duke NC. Overlap of eastern and western mangroves in the South-Western Pacific: Hybridization of all three Rhizophora (Rhizophoraceae) combinations in New Caledonia. Blumea Journal of Plant Taxonomy and Plant Geography. 2010;55:171-188. DOI: 10.3767/ $000651910 \times 527293$

[52] Hyde K, Jones E, Leano E, et al. Role of marine fungi in marine ecosystems. Biodiversity and Conservation. 1998;7:1147-1161

[53] Sarma VV, Hyde KD. A review on frequently occurring fungi in mangroves. Fungal Diversity. 2011;8:1-34

[54] Baltazar. A checklist of xylophilous basidiomycetes (Basidiomycota) in mangroves. Mycotaxon. 2009;107:221-224 
[55] Cribb AB, Cribb JW. Marine Fungi from Queensland. Vol. 3. Brisbane: Department of Botany, University of Queensland Press; 1955. pp. 97-105

[56] Hyde KD. A comparison of the intertidal mycota of five mangrove tree species. Asian Marine Biology. 1990;7:93-107

[57] Schmit JP, Shearer CAA. A checklist of mangrove-associated fungi, their geographical distribution and known host plants. Mycotaxon-Ithaca, NY. 2003;85(1):423-477

[58] Schmit JP, Shearer CA. Geographic and host distribution of lignicolous mangrove microfungi. Botanica Marina. 2004;47:496-500. DOI: 10.1515/BOT.2004.065

[59] Liu AR, Wu XP, Xu T. Research advances in endophytic fungi of mangrove. Chinese Journal of Applied Ecology. 2007;13:366-378

[60] Hyde KD, Jones EBG. Marine mangrove fungi. Marine Ecology. 1988;9:15-33

[61] Peng X, Wang Y, Sun K, et al. Cerebrosides and 2-pyridone alkaloids from the halotolerant fungus Penicillium chrysogenum grown in a hypersaline medium. Journal of Natural Products. 2011;74:1298-1302. DOI: 10.1021/np1008976

[62] Gao SS, Li XM, Williams K, et al. Rhizovarins A-F, indole-diterpenes from the mangrovederived endophytic fungus Mucor irregularis QEN-189. Journal of Natural Products. 2016;79:2066-2074. DOI: 10.1021/acs.jnatprod.6b00403

[63] Zang LY, Wei W, Guo Y, et al. Sesquiterpenoids from the mangrove-derived endophytic fungus Diaporthe sp. Journal of Natural Products. 2012;75:1744-1749. DOI: 10.1021/ np3004112

[64] Sun H, Gao SS, Li XM, et al. Chemical constituents of marine mangrove-derived endophytic fungus Alternaria tenuissima EN-192. Chinese Journal of Oceanology and Limnology. 2013;31:464-470

[65] Klaiklay S, Rukachaisirikul V, Tadpetch K, et al. Chlorinated chromone and diphenyl ether derivatives from the mangrove-derived fungus Pestalotiopsis sp. PSU-MA69. Tetrahedron. 2012;68:2299-2305. DOI: 10.1016/j.tet.2012.01.041

[66] Klaiklay S, Rukachaisirikul V, Phongpaichit S, et al. Flavodonfuran: A new difuranylmethane derivative from the mangrove endophytic fungus Flavodon flavus PSU-MA201. Natural Product Research. 2013;27:1722-1726. DOI: 10.1080/14786419.2012.750315

[67] Buatong J, Phongpaichit S, Rukachaisirikul V, et al. Antimicrobial activity of crude extracts from mangrove fungal endophytes. World Journal of Microbiology and Biotechnology. 2011;27:3005-3008. DOI: 10.1007/s11274-011-0765-8

[68] Kumaresan V, Suryanarayanan TS. Endophyte assemblages in young, mature and senescent leaves of Rhizophora apiculata: Evidence for the role of endophytes in mangrove litter degradation. Fungal Diversity. 2002;9:81-91

[69] Xu J, Kjer J, Sendker J, et al. Cytosporones, coumarins, and an alkaloid from the endophytic fungus Pestalotiopsis sp. isolated from the Chinese mangrove plant Rhizophora mucronata. Bioorganic \& Medicinal Chemistry. 2009;17:7362-7367. DOI: 10.1016/j.bmc. 2009.08.031 
[70] Shiono $\mathrm{Y}$, Sasaki T, Shibuya F, et al. Isolation of a phomoxanthone A derivative, a new metabolite of tetrahydroxanthone, from a Phomopsis sp. isolated from the mangrove, Rhizhopora mucronata. Natural Product Communications. 2013;8:1735-1737

[71] Ananda K, Sridhar KR. Diversity of endophytic fungi in the roots of mangrove species on the west coast of India. Canadian Journal of Microbiology. 2002;48:871-878. Source: PubMed. DOI: 10.1139/w02-080

[72] Beau J, Mahid N, Burda WN, et al. Epigenetic tailoring for the production of anti-infective cytosporones from the marine fungus Leucostoma persoonii. Marine Drugs. 2012;10: 762-774. DOI: $10.3390 / \mathrm{md} 10040762$

[73] Sebastianes FLDS, Romão-Dumaresq AS, Lacava PT, et al. Species diversity of culturable endophytic fungi from Brazilian mangrove forests. Current Genetics. 2013;59:153-166. DOI: $10.1007 / \mathrm{s} 00294-013-0396-8$

[74] Wier AM, Tattar TA, Klekowski EJ. Disease of red mangrove (Rhizophora mangle) in Southwest Puerto Rico caused by Cytospora rhizophorae. Biotropica. 2000;32:299-306. DOI: $10.1111 /$ j.1744-7429.2000.tb00473.x

[75] Wheeler MH, Stipanovic RD, Puckhaber LS. Phytotoxicity of equisetin and epi-equisetin isolated from Fusarium equiseti and F. pallidoroseum. Mycological Research. 1999;103: 967-973. DOI: 10.1017/S0953756298008119

[76] Wang J, Lu W, Min C, et al. The endophytic fungus AGR12 in the stem of Rhizophora stylosa Griff and its antibacterial metabolites. Chinese Journal of Antibiotics. 2011;36:102-106

[77] Burmeister HR, Bennett GA, Vesonder RF, et al. Antibiotic produced by Fusarium equiseti NRRL 5537. Antimicrobial Agents and Chemotherapy. 1974;5:634-639. DOI: 10.1128/ AAC.5.6.634

[78] König T, Kapus A, Sarkadi B. Effects of equisetin on rat liver mitochondria: Evidence for inhibition of substrate anion carriers of the inner membrane. Journal of Bioenergetics and Biomembranes. 1993;25:537-545. DOI: 10.1007/BF01108410

[79] Xu J, Ebada SS, Proksch P. Pestalotiopsis, a highly creative genus: Chemistry and bioactivity of secondary metabolites. Fungal Diversity. 2010;44:15-31. DOI: 10.1007/s13225010-0055-z

[80] Xu J, Kjer J, Sendker J, et al. Chromones from the endophytic fungus Pestalotiopsis sp. isolated from the Chinese mangrove plant Rhizophora mucronata. Tetrahedron Letters. 2011;52:21-25. DOI: 10.1021/np800748u

[81] Xu J, Lin Q, Wang B, et al. Pestalotiopamide E, a new amide from the endophytic fungus Pestalotiopsis sp. Journal of Asian Natural Products Research. 2011;13:373-376. DOI: 10.1080/10286020.2011.554829

[82] An CY, Li XM, Li CS, et al. Aniquinazolines A-D, four new quinazolinone alkaloids from marine-derived endophytic fungus Aspergillus nidulans. Marine Drugs. 2013;11: 2682-2694. DOI: $10.3390 / \mathrm{md} 11072682$ 
[83] Fan Y, Yi W, Liu P, et al. Indole-diterpenoids with anti-H1N1 activity from the aciduric fungus Penicillium camemberti OUCMDZ-1492. Journal of Natural Products. 2013;76: 1328-1336. DOI: $10.1021 / n p 400304 q$

[84] Rukachaisirikul V, Sommart U, Phongpaichit S, et al. Metabolites from the endophytic fungus Phomopsis sp. PSU-D15. Phytochemistry. 2008;69:783-787. DOI: 10.1016/j. phytochem.2007.09.006

[85] Zhang P, Li X, Wang BG. Secondary metabolites from the marine algal-derived endophytic fungi: Chemical diversity and biological activity. Planta Medica. 2016;82:832-842. DOI: $10.1055 / \mathrm{s}-0042-103496$

[86] Liu T, Li ZL, Wang Y, et al. A new alkaloid from the marine-derived fungus Hypocrea virens. Natural Product Research. 2011;25:1596-1599. DOI: 10.1080/14786419.2010.490916

[87] Hemberger Y, Xu J, Wray V, et al. Pestalotiopens A and B: Stereochemically challenging flexible sesquiterpene-cyclopaldic acid hybrids from Pestalotiopsis sp. Chemistry - A European Journal. 2013;19:15556-15564

[88] Wani MC, Taylor HL, Wall ME, et al. Plant antitumor agents. VI. The isolation and structure of taxol, a novel antileukemic and antitumor agent from Taxus brevifolia. Journal of the Chemical Society. 1971;93:2325-2327

[89] Harrison JW, Scrowston RM, Lythgoe B. Taxine. Part IV. The constiuents of taxine-I. Journal of the Chemical Society. 1996;95:641-655

[90] Stierle A, Strobel G, Stierle D, et al. The search for a taxol-producing microorganism among the endophytic fungi of the Pacific Yew, Taxus brevifolia. Journal of Natural Products. 1995;58:1315. DOI: 10.1021/np50123a002

[91] Strobel G, Yang X, Sears J, et al. Taxol from Pestalotiopsis microspora, an endophytic fungus of Taxus wallachiana. Microbiology. 1996;142:435-440. DOI: 10.1099/13500872-142-2-435

[92] Chen J, Qiu X, Wang R, et al. Inhibition of human gastric carcinoma cell growth in vitro and in vivo by cladosporol isolated from the paclitaxel-producing strain Alternaria alternata var. monosporus. Biological \& Pharmaceutical Bulletin. 2009;32:2072-2074. DOI: 10.1002/(SICI)1097-0215(19991008)83:2<283::AID-IJC22>3.0.CO;2-6

[93] Xu F, Tao W, Cheng L, et al. Strain improvement and optimization of the media of taxolproducing fungus Fusarium maire. Biochemical Engineering Journal. 2006;31:67-73. DOI: 10.1016/j.bej.2006.05.024

[94] Huang M, Li J, Liu L, et al. Phomopsichin A-D; four new chromone derivatives from mangrove endophytic fungus Phomopsis sp. 33\#. Marine Drugs. 2016;14:215-220. DOI: 10.3390/md14110215

[95] Amagata T, Morinaka BI, Amagata A, et al. A chemical study of cyclic depsipeptides produced by a sponge-derived fungus. Journal of Natural Products. 2006;9:1560-1565 
[96] Rukachaisirikul V, Rodglin A, Phongpaichit S, et al. $\alpha$-Pyrone and seiricuprolide derivatives from the mangrove-derived fungi Pestalotiopsis spp. PSU-MA92 and PSU-MA119. Phytochemistry Letters. 2012;5:13-17

[97] Brady SF, Wagenaar MM, Singh MP, et al. The cytosporones, new octaketide antibiotics isolated from an endophytic fungus. Organic Letters. 2000;32:4043-4046. DOI: 10.1021/ ol006680s

[98] Helms JB, Rothman JE. Inhibition by brefeldin A of a Golgi membrane enzyme that catalyses exchange of guanine nucleotide bound to ARF. Nature. 1992;360:352-354. DOI: $10.1038 / 360352 \mathrm{a} 0$ 